Original scientific paper

Submitted: 2020-02-20

doi:10.5937/nabepo25-25323

Published: 2020-07-17

\title{
COMMUNITY POLICING IMPLEMENTATION IN THE REPUBLIC OF SERBIA: A VIEW FROM THE MANAGERS'S PERSPECTIVE
}

\author{
Dragan Milidragović ${ }^{1}$ \\ Ministry of the Interior of the Republic of Serbia, Belgrade, Serbia
}

\section{Nenad Milić}

University of Criminal Investigation and Police Studies, Belgrade, Serbia

\author{
Nebojša Dragović \\ Ministry of the Interior of the Republic of Serbia, \\ Police Department for the City of Belgrade, Serbia
}

\begin{abstract}
Activities aimed at bringing the police closer to the local community and promoting the building of partnerships and common solutions to security problems are referred to as community policing. In the Republic of Serbia, community policing implementation formally started in 2003 through the 'Community Policing' project. After the initial period of implementation, community policing principles were expected to become part of the organizational culture of police organization and a distinctive feature of everyday police practice. Based upon research results presented in this paper, the authors sought to determine to what extent the concept of community policing came to fruition in Serbian police practice and how it works today.

The research was directed towards the middle management of the Serbian police, where the sample included all regional police departments in Serbia. The paper concluded that at the time this research was conducted, community policing was not sufficiently implemented in the Serbian police practice, that reactive work still dominated over prevention and proactive work, the organizational structure did not allow greater representation of $\mathrm{CP}$ activities, there was a need for additional training of police officers and the legislation which could facilitate partnership between the police and the community was missing.

Keywords: police reform, crime prevention, partnership, community policing officers, problem solving, organizational changes.
\end{abstract}

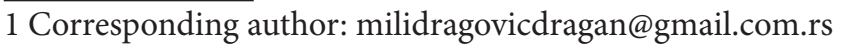




\section{INTRODUCTION}

Evidence gathered showed that the reactive policing, based upon traditional law enforcement activities and tactics, have not been effective (Bayley, 1994). The focus of traditional policing is to respond to individual incidents rather than to address causes of these incidents (Goldstein, 1990). In order to control crime, police must act on the causes and conditions leading to its occurrence ( $\mathrm{Si}$ monović, 2006). However, these causes and conditions are, as a rule, beyond the reach of police action, hence there is a need to mobilize other entities in community to jointly counter crime. When it was realized the police alone could not counter crime, and especially some factors affecting citizens' quality of life, it became clear that partnership with the community became an important element of exercising police function (Diamond \& Weiss, 2009).

Police, citizens, and other entities in the local community have begun to cooperate and jointly address security concerns. These changes in police work marked the beginning of community policing. Community policing (hereinafter referred to as $\mathrm{CP}$ ) represents a major change in policing practice that features shifting law enforcement's focus away from crime control (Trojanowicz \& Bucqueroux, 1990; Diamond \& Weiss, 2009). Since the inception of the $\mathrm{CP}$, different definitions and practices have been associated with it (Young and Tinsley, 1998; Palmiotto, 2000; Brookes, 2006). Despite numerous definitions, three components are often emphasized, implying the existence of some consensus among academics and practitioners, when it comes to conceptualization of CP. These elements are: partnership between police and community, problem solving and organizational transformation (Moore, 1992; Cordner, 1997; Maguire \& Mastrofski, 2000; Skogan, 2004; Lorie, 2004; Gill et al., 2014).

If we take into account that many problems which require police attention arise and manifest themselves in the local community, then the establishment and maintenance of partnerships with the community is a prerequisite for the efficient police work. In the essence of such partnership is establishing and maintaining trust between police and community members - the goal that cannot be achieved overnight, but requires on-going effort and sustaining commitment (Bureau of Justice Assistance, 1994). Frequent contacts, mutual trust and strong partnership allow citizens and police officers to better understand each other, resulting in the increased respect and legitimacy of the police (Kelling, 1988) and safer communities.

Efforts intended to establish partnership will be doomed to failure if police do not allow citizens to have a voice in defining the problems and opportunity to participate in their solving. Hence the other CP 'pillar' - problem solving - is closely related to partnership. True partnership could not exist without expressing interest for community problems by the police. At the same time, if trying to identify and solve community problems police could not be effective enough acting on their own, without any community input and/or suport. A community is believed to possess knowledge and resources, which can significantly contribute police officers' efforts, not only in preventing and solving crime (Moore et al., 2000), but to respond to a much wider array of problems that affect quality of life, which can sometimes raise greater 
citizens concern than crime itself (Miller et al., 2008: 270).

By actively seeking public cooperation through increased contacts with citizens and exchange of information, the police can significantly enhance their ability to prevent crime (Moore et al., 2000). Crime prevention is central to the concept and ultimate goal of community policing (Skolnick \& Bayley, 1988). Like traditional policing, where police is mostly engaged into responding to crime, CP emphasizes identification of the underlying conditions that lead to crime, before they grow into major crime problems. Hence, the extent to which crime prevention and problem solving activities are represented in police practice can be an important indicator of the quality of CP implementation in particular police organisation.

Treating citizens only as 'eyes and ears' is one way street police should not go. Even before community policing, police were aware of their dependence on community as a resource to solving crime (which is the primary focus of traditional model), citizens were never asked what had to be done in order to gain their help and support that exceeded merely crime reporting and/or providing suspect(s) description. It was thought that citizens' interest to live in a safer community was sufficient to motivate 'partnership' with police (Milić, 2017). It turned out that this was the wrong assumption and community policing was born on these and similar lessons learnt from the past.

In order to establish and maintain partnership police organisation must rely more on foot patrol, where officers should be put on permanent beats, so they are able to know residents and be aware of community safety issues (Cowell \& Kringen, 2016). In order to facil- itate problem solving, officers must be given the flexibility to handle problems in a way that they believe is most effective, rather than being constrained by rigid bureaucratic rules and procedures (Skogan et al., 1999). They need to have access to more information including greater support from crime analysis unit (Cordner \& Biebel, 2005; Milic et al., 2017). These and other changes in police practice require restructuring of traditional, bureaucratic police organization. Although not necessary prerequisites to implement $\mathrm{CP}$, decentralization and flattening of the layers of hierarchy may significantly facilitate CP implementation (Diamond \& Weiss, 2009). Crime fighting should not be considered as 'the only' and 'the real' police work and that should be recognized, not only in the organization's mission statement, but in performance measurement system too. If there is no coherent message that activities which reflect community policing will be supported and rewarded, a change of behaviour will probably be missing.

In order for community policing to be successful, the system of recruitment, selection and training should also be changed. The police officers' selection process must take into account interpersonal skills, communication skills and problem-solving skills - skills that were often neglected under the traditional system. As CP brings changes to many areas of policing and requires some new skills, training and education become essential elements in the implementation of CP activities (Zhao et al., 1995; Haar, 2001). Without proper training, officers will be less likely to understand the philosophy of community policing and/or how to translate it into everyday practice (King \& Lab, 2000). Research has consistently shown that progress made in 
$\mathrm{CP}$ implementation, rarely was followed by changes in the way officers were trained - classes related to traditional crime-fighting strategies continued to dominate academy and field training curriculum, years after the inception of CP program (Chappell, 2009).

In the most European countries, the implementation of the CP began at the end of the last century, while in the Republic of Serbia, the implementation of this concept formally commenced in 2003 (Vojnović, 2004). The implementation process was divided into two phases. The first phase was the pilot phase in which the initial experience was gained in applying the new working method. In the second phase, numerous activities were undertaken in the field of establishing cooperation with local self-government representatives. After the second phase, the Serbian police were supposed to undertake certain preventive activities in their daily work and implement prevention projects aimed at improving security at the local level.

Since CP inception, the Serbian Ministry of Interior (MOI) has been going through reform processes during which different attention has been paid to the $\mathrm{CP}$ activities. In that regard, this paper presents the results of research that was aimed to assess the extent to which partnership, problem solving and the existing organizational structure - as the three pillars of the $\mathrm{CP}$ - are represented in police practice, to identify problems which hinder CP implementation and to offer recommendations on how they can be overcome.

\section{COMMUNITY POLICING IMPLEMENTATION IN SERBIAN POLICE - THE EMPIRICAL STUDY}

The research presented in this paper was conducted from March to June 2014, with the aim of assessing the quality of CP implementation, after a ten-year period of its implementation in the Serbian police practice, to identify the problems that hinder its implementation and to offer some recommendations for overcoming them. Particularly, the research sought to determine, from the (middle) management perspective, the extent to which there is an orientation towards preventive police work, the extent to which the existing organizational structure is aligned to the needs of CP implementation, whether there is a need for additional training of police officers, to assess the community's readiness to cooperate with the police, as well as the extent to which strategic level of police management encourages and directs the $\mathrm{CP}$ activities.

\section{SAMPLE AND RESEARCH METHOD}

The research was conducted between March and June 2014, through surveys and interviews. The survey questioned
359 police officers from all 27 police departments in Serbia. The respondents were heads within the regional police de- 
partments ${ }^{2}$ (chiefs of General Police Division, deputy chiefs, heads of section), heads within police stations (commanders, deputy and assistant commanders) and executive officers in the regional General Police Divisions.

More than half of the surveyed police officers, $188(52.4 \%)$ of them, were heads in a police station (commander, deputy, and assistant commander). The survey included 138 (38.4\%) executive officers in the General Police Division/Department, as well as $33(9.2 \%)$ heads in the Police Division/Department (chief, deputy chief, head of section) (Table 1).

Table 1. Overview of respondents (research sample) by position in the Ministry of Interior

\begin{tabular}{|c|c|c|c|c|c|}
\hline \multicolumn{6}{|c|}{ RESEARCH SAMPLE } \\
\hline \multirow{2}{*}{$\begin{array}{c}\text { Management } \\
\text { level }\end{array}$} & \multirow{2}{*}{$\begin{array}{c}\text { Organisational } \\
\text { unit }\end{array}$} & \multirow{2}{*}{$\begin{array}{c}\text { Teritorrial } \\
\text { responsibility }\end{array}$} & \multirow[b]{2}{*}{ Position } & \multicolumn{2}{|c|}{$\begin{array}{l}\text { Number of } \\
\text { participants }\end{array}$} \\
\hline & & & & $\begin{array}{l}\text { Survey } \\
(\mathrm{N})\end{array}$ & $\begin{array}{l}\text { Inter- } \\
\text { view } \\
(\mathrm{N})\end{array}$ \\
\hline STRATEGIC & $\begin{array}{c}\text { Uniformed Police } \\
\text { Department } \\
\text { (Police } \\
\text { Directorate) }\end{array}$ & $\begin{array}{l}\text { Republic } \\
\text { of Serbia }\end{array}$ & $\begin{array}{c}\text { Head of Department } \\
\text { for Prevention and } \\
\text { Community Policing } \\
\text { Activities }\end{array}$ & / & 1 \\
\hline \multirow{4}{*}{ MIDDLE } & \multirow{4}{*}{$\begin{array}{c}\text { General Police } \\
\text { Divisions } \\
\text { (26 regional PD) } \\
+ \\
\text { General Police } \\
\text { Department } \\
\text { (Belgrade PD) }\end{array}$} & \multirow{4}{*}{$\begin{array}{c}\text { Region }(3+ \\
\text { municipalities) }\end{array}$} & $\begin{array}{l}\text { Head of General } \\
\text { Police Division }\end{array}$ & \multirow{3}{*}{33} & / \\
\hline & & & Deputy head & & I \\
\hline & & & Section chief & & 4 \\
\hline & & & $\begin{array}{l}\text { Executive Officers } \\
\text { (rank of police } \\
\text { captain and above) }\end{array}$ & 138 & / \\
\hline \multirow{3}{*}{ TACTICAL } & \multirow{3}{*}{ Police station } & \multirow{3}{*}{1 municipality } & $\begin{array}{l}\text { Police station } \\
\text { commander }\end{array}$ & \multirow{3}{*}{188} & / \\
\hline & & & Deputy commander & & l \\
\hline & & & Assistant commander & & 1 \\
\hline & & & TOTOAL & 359 & 5 \\
\hline
\end{tabular}

The survey contained five questions about community policing. Answers to these questions are presented and analysed in this paper.

The largest number of respondents, 264 of them $(73.5 \%)$ had more than 10 years of service, which means that most of the respondents had the opportunity to (historically) assess the whole period from the beginning of $\mathrm{CP}$ implementation to the time when the survey was conducted (Table 2).

2 All regional police departments, except Police Department for the City of Belgrade have General Police Division. Belgrade Police Department has General Police Department. 
Table 2. Years of service of respondents in the Ministry of Interior

\begin{tabular}{cccc}
\hline Years of service & N & \% & Cumulative \% \\
\hline$<5$ & 24 & 6,7 & 6,7 \\
$5-10$ & 71 & 19,8 & 26,5 \\
$11-15$ & 100 & 27,9 & 54,3 \\
$16-20$ & 59 & 16,4 & 70,8 \\
$21-25$ & 60 & 16,7 & 87,5 \\
$26-30$ & 23 & 6,4 & 93,9 \\
$\geq 31$ & 22 & 6,1 & 100 \\
\hline
\end{tabular}

Police station heads (commander, deputy, and assistant commander) at the time of surveying had 5 to 15 years of work experience. Executive officers in the General Police Division/Department mostly had work experience of 11 to 15 years, while heads in the General Police Division/Department (chief, deputy chief, head of unit) at the time of surveying had 21 to 30 years of work experience in the Ministry of Interior (Figure 1).

The respondents differed statistically significantly by work experience in the Ministry of Interior and their respective position $(\chi 2=32,634 ; \mathrm{df}=12 ; \mathrm{p}=$ $0,001)$.

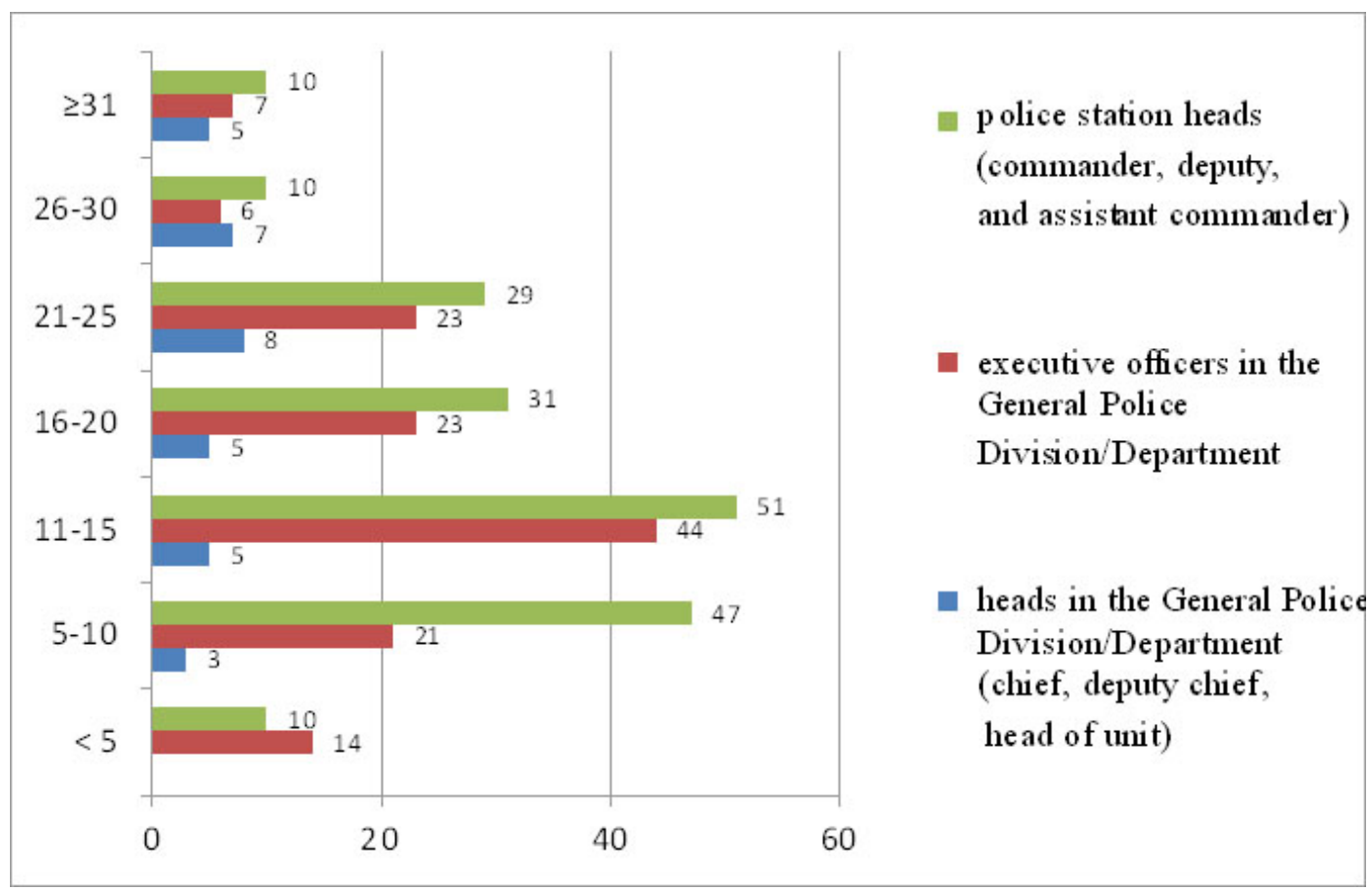

Figure 1. Overview of respondents relative to their position and years of work experience

The collected data were entered into a zation and categorization of data, staspecially created database for each re- tistical data processing was performed spondent in MS Excel. After systemati- using the IBM SPSS 20. Descriptive 
statistics determined the frequency and percentage ( $\mathrm{N}$ and \%). Categorical variables were compared by the Chi-square test and the Fisher's exact test. Statistically significant value was estimated at the level of $\mathrm{p}<0.05$.

The interview was conducted with four middle level managers and one manager of the highest (strategic) level of the police organization. The interview was conducted with the heads of the Section for Organization, Prevention, Training and Community Policing in the regional police departments of Novi Sad, Kragujevac and Niš, as well as with the head of the Unit for Prevention and Community Policing in the Police Department for City of Belgrade. These are the four largest and most security-laden police departments in Serbia. Finally, interview was conducted with the Head of the Department for Prevention and Community Policing Activities in the General Police Department, at the Police Directorate department that supervises the $\mathrm{CP}$ implementation on the entire territory of Serbia. The interviewees had more than 10 years of experience, which is expected taking into account the positions they hold. Interviewees were asked to answer a total of 15 questions. $^{3}$

\section{RESEARCH RESULTS}

\section{Survey results}

CP implementation was expected to make preventive work one of the basic contents in everyday police work. In an effort to verify the correctness of this attitude, the respondents were asked: Are preventive activities represented in the police daily work? Responding to this question, the largest number of respondents, i.e. $310(86.4 \%)$ of them, stated that preventive activities were not represented in the police daily work, while a smaller number of respondents, 49 (13.6\%) of them, considered preventive activities were represented in the police daily work $(\chi 2=189,752 ; \mathrm{df}=1 ; \mathrm{p}=0,000)$ (Table 3$)$.

3 The respondents were asked the following questions: 1. Which jobs belong to your organizational unit competence? 2. What activities (measures and actions) are taken by your organizational unit in the field of community policing? 3. Have any preventative effects of community policing been achieved so far? 4. In which way does community policing function in your Police Division /Republic of Serbia today? 5. What problems are present today in the work of community policing, and how should current issues be addressed? 6 . Are projects of problem-oriented community policing implemented at the PD/RS level? 7. Who initiates problem-oriented police work projects (police stations, Police departments/division, Police Division at the headquarters of the Police Directorate) and do they represent a real need to apply problem-oriented work or just a form? 8. Are police officers in the sector, sector leaders, and heads in police stations educated and trained for community policing? 9. In what way should community policing be organized in the Republic of Serbia? 10. Has Police Division at the Police Directorate headquarters communicated any guidelines for the implementation of the Community Policing Strategy? 11. Is it necessary to systematize a special organizational unit within the police station in charge only of prevention and community policing? 12. Are the subjects in the local community willing to cooperate with the police in taking preventive activities? 13 . Can the current organization of community policing achieve preventive effects? 14. What changes in work are necessary to implement community policing? 15 . Are preventive activities today represented in the daily work of the police? And if not, why is that so? At the end of the interview, the respondents were given the opportunity to express their opinion and make suggestions about improving community policing. 
Table 3. Representation of preventive activities in the daily police work

\begin{tabular}{lccc}
\hline & N & \% & Significance \# \\
\hline Yes $^{\mathrm{a}}$ & 310 & 86,4 & $\mathrm{a} / \mathrm{b}^{* * *}$ \\
No $^{\mathrm{b}}$ & 49 & 13,6 & \\
Total & 359 & 100 & \\
\hline${ }^{\text {"Chi-square test; }}{ }^{* * *} \mathrm{p}<0,001$ & & \\
\hline
\end{tabular}

It is interesting to analyse the structure of respondents' answers relative to their position and years of service in the Ministry of Interior (Figures 2 and 3).

Approximately the same percentage of the respondents who work as executive officers in General Police Division/Department (88.4\%), and in the position of a head in a police station (86.2\%) believe that preventive activities are not represented in the daily work of the police. When it comes to heads in General Police Division/Department, a slightly lower percentage of the respondents $(78.8 \%)$ agree with this view. This difference is statistically significant $\left(\chi^{2}=94,555 ; \mathrm{df}=\right.$ $2 ; \mathrm{p}=0,000$ ) (Figure 3).

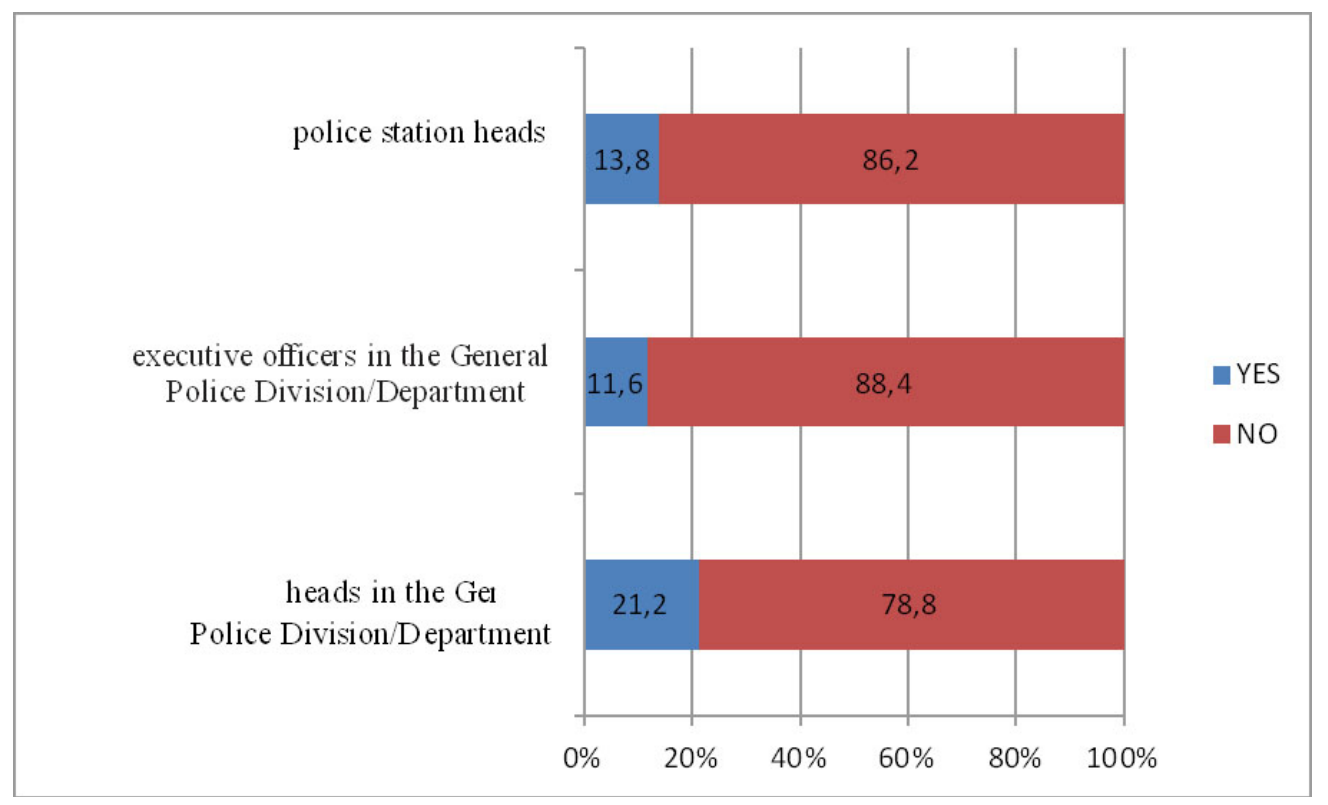

Figure 2. Representation of preventive activities in the daily work of the police relative to the position respondents hold

Most of the respondents, regardless of their years of service, consider preventive activities are not represented in the daily work of the police. It is interesting that all, that is, $100 \%$ of respondents, who work in the Ministry of Interior for 26 to 30 years, believe that preventive activities are not represented in the daily work of the police. A slightly smaller percentage of the respondents who have been working for over 30 years $(90.9 \%)$ also consider preventive activities are not represented in the daily work of the police. Within subgroups of respondents 
who answered YES $(\chi 2=14.306 ; \mathrm{df}=5$; $\mathrm{p}=0.014)$ and those who answered NO $\left(\chi^{2}=87,419 ; \mathrm{df}=6 ; \mathrm{p}=0,000\right)$ there is a statistically significant difference depending on the length of service in the MoI (Figure 3).

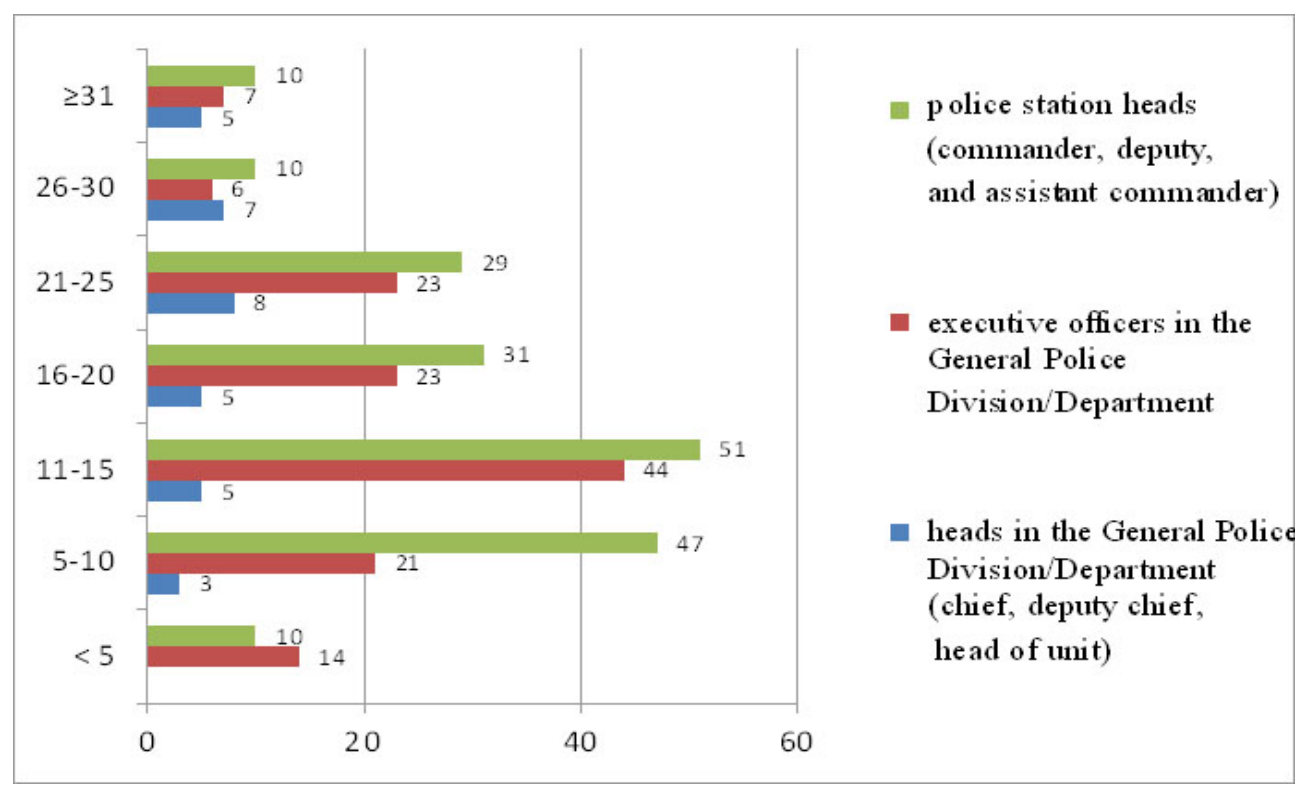

Figure 3. Respondents' opinion on the representation of preventive activities depending on the years of service in the Serbian police

The respondents who answered negatively to the question were given the opportunity to comment on the reasons why preventive activities are not represented in the daily work of the police. Most of the respondents, 285 (79.4\% of the total sample), who answered negatively to this question, believe that preventive activities are not represented because of the heavy workload of the police with numerous requests and orders issued from government bodies (e.g. Courts) the police are expected to handle, the lack of appreciation of preventive work results, the lack of obligation for preventive action, insufficient education on the CP work, strong repressive orientation of the police service, a small number of police officers in police stations, the lack of motivation of police officers and awareness of the importance of community policing (Plačkov 2008;
Milić, 2010; Đorović, 2011; Milidragović et al., 2019).

Problem-solving projects, with the emphasis on identification and addressing problems' root causes, are a way of solving security and other problems in the local community in a more sustainable way. In these projects, the police and the community, as partners, take part equally in problem solving, thus developing partnership and cooperation, as the key components of the CP concept. When it comes to practical implementation of these projects, the respondents were asked the following question: Are projects of problem-oriented police work planned and implemented in your organizational unit (PD and PS)? Responding to this question, the largest number of respondents, 221 (61.6\%) of them, considered that projects were implemented only at the behest of higher levels of 
management, while 58 (16.2\%) of respondents claimed that no projects were implemented on an annual basis. Moreover, 71 (19.8\%) respondents believe that several projects were implemented on one's own initiative during the year. The results of the answer to this question tell us that projects of problem-oriented work in police departments were occasionally realized, most often at the behest of higher levels of management.
Statistically viewed, a significant majority $(p<0.001)$ of respondents believe that projects are implemented only by order of higher levels of police management, while those who claim that no project was implemented on an annual basis and those who did not write a response were a significant majority $(\mathrm{p}<0.001)$ (Table 4).

Table 4. Representation of problem solving activities in the Serbian police practice

\begin{tabular}{lccc}
\hline & N & $\%$ & Significance \# \\
\hline $\begin{array}{l}\text { Projects are implemented only by order } \\
\text { of higher levels of management }\end{array}$ & 221 & 61,6 & $\mathrm{a} / \mathrm{b}, \mathrm{c}, \mathrm{d}^{* * *}$ \\
$\begin{array}{l}\text { Not a single project has been implemented } \\
\text { on an annual basis }\end{array}$ & 58 & 16,2 & $\mathrm{~b} / \mathrm{d}^{* * *}$ \\
$\begin{array}{l}\text { Several projects were implemented during } \\
\text { the year, on own initiative }\end{array}$ & 71 & 19,8 & $\mathrm{c} / \mathrm{b}, \mathrm{d}^{* * *}$ \\
$\begin{array}{l}\text { Not answered } \\
\text { Total }\end{array}$ & 9 & 2,4 & \\
\hline
\end{tabular}

${ }^{*}$ Chi-square test; ${ }^{* * *} \mathrm{p}<0,001$

CP implementation can also be carried out by specialized police officers whose only responsibility is community policing. Relieved from other activities, they are able to put more energy and commitment into $\mathrm{CP}$ activities than regular patrol officers. The countries where the $\mathrm{CP}$ work is organized in this way have recorded greater confidence of citizens in the police, better cooperation between them, reduction in crime rates and active participation of citizens in solving local problems (Forman, 2004; Feltes, 2013; Lobnikar et al., 2015:512). On the introduction of specialized community policing officers, the respondents were asked: Is it necessary to establish com- munity policing officer positions in police stations? Responding to this question, $246(68.5 \%)$ of respondents believe that community policing officer position in police stations should be systematized, $86(24 \%)$ believe this is not necessary, while $26(7.2 \%)$ of them said that police officers in the security sector are able to carry out tasks in the CP field on top of regular policing. More than half of the respondents believe that overload by regular tasks makes it impossible to undertake the activities within the scope of $\mathrm{CP}$ concept, which is why they consider it justified to systematize the community policing officer's position (Table 5). 
Table 5. Systematization of the community policing officer's position

\begin{tabular}{lccc}
\hline & $\mathbf{N}$ & $\%$ & Significance \# \\
\hline Yes $^{\mathrm{a}}$ & 246 & 68,5 & $\mathrm{a} / \mathrm{b}, \mathrm{c}^{* * *}$ \\
No $^{\mathrm{b}}$ & 86 & 24 & $\mathrm{~b} / \mathrm{c}^{\star * *}$ \\
$\begin{array}{l}\text { Police officers in the security sector are able } \\
\text { to do community policing work in addition }\end{array}$ & 26 & 7,2 & \\
to regular policing tasks & & & \\
Not answered & 1 & 0,3 & \\
Total & 359 & 100 & \\
\hline
\end{tabular}

${ }^{\#}$ Chi-square test; ${ }^{* * *} \mathrm{p}<0,001$

Knowledge of police officers on CP philosophy and its importance, on the effects that can be achieved (increasing cooperation with citizens, reducing crime rates, etc.) is one of the most important conditions for CP implementation. It is a precursor to change of attitudes. Knowledge and skills about $\mathrm{CP}$ can only be gained through the police training and education, which is why the respondents were asked the following: Do you think that your police department needs addi- tional training of police officers in $C P$ ? In response to this question, 275 (76.6\%) of respondents said that additional training in $\mathrm{CP}$ of all police officers (chiefs, executive officers, commanders, sector heads and police officers in the security sector) was needed, 43 (12\%) of them said that only front line police officers and sector heads need to be educated, while 39 (10.9\%) respondents believed it was not necessary to educate police officers about the CP (Table 6).

Table 6. The need of additional training of police officers about community policing

\begin{tabular}{lccr}
\hline & $\mathbf{N}$ & $\mathbf{\%}$ & Significance \# \\
\hline $\begin{array}{l}\text { Yes, there is a need for additional training for } \\
\text { all police officers (chiefs, executive officers, }\end{array}$ & 275 & 76.6 & $\mathrm{a} / \mathrm{b}, \mathrm{c}^{* * *}$ \\
$\begin{array}{l}\text { commanders, sector heads and police officers } \\
\text { in the security sector) }\end{array}$ & & & \\
$\begin{array}{l}\text { There is no need for additional training } \\
\text { related to CP }\end{array}$ & 39 & 10,9 & \\
$\begin{array}{l}\text { There is a need for additional training only for } \\
\text { front line police officers and sector heads }\end{array}$ & 43 & 12 & \\
$\begin{array}{l}\text { Not answered } \\
\text { Total }\end{array}$ & 2 & 0,5 \\
\hline
\end{tabular}

${ }^{*}$ Chi-square test; ${ }^{* * *} \mathrm{p}<0,001$

CP implementation has also resulted in organizational adaptation of the police organization. Within the Uniformed Police Department at the Police Direc- torate and within the Uniformed Police Department for the City of Belgrade new organizational units for crime prevention and community policing were 
established. Regional police departments have envisaged executive officers' positions for the CP (rank of captain and above). Within the police stations there were neither special organizational unit for CP nor special positions (e.g. CP officers) for performing these tasks. In order to determine the functionality of this model of organization, we asked the respondents the following: How functional is the current model of police organisation for performing preventive and repressive tasks? When asked, $75 \%$ of the respond- ents said that the current model of the police organizational structure was not functional for exercising the preventive and repressive function of the police. A smaller number of the respondents, 68 out of 359 (19\%), stated that the current model of the police organizational structure was functional for exercising preventive and repressive function, and for $21(6 \%)$ respondents the present model was effective only for repressive action (Table 7).

Table 7. Functionality of police organization's structure

\begin{tabular}{lccc}
\hline & $\mathbf{N}$ & $\%$ & Significance \# \\
\hline $\begin{array}{l}\text { It is not functional for the fulfilment of the } \\
\text { preventive-repressive function of the police }\end{array}$ & 270 & 75 & $\mathrm{a} / \mathrm{b}, \mathrm{c}^{* * *}$ \\
$\begin{array}{l}\text { It is functional for the fulfilment of the preventive- } \\
\text { repressive function of the police }\end{array}$ & 68 & 19 & $\mathrm{~b} / \mathrm{c}^{* * *}$ \\
$\begin{array}{l}\text { It is functional for repressive activities only } \\
\text { Total }\end{array}$ & 21 & 6 & \\
\hline
\end{tabular}

${ }^{\#}$ Chi-square test; ${ }^{* *} \mathrm{p}<0,001$

\section{Interview results}

The interviewees were asked a total of 15 questions. The questions were grouped into sections related to the competence of the organizational units managed by the respondents, activities undertaken and preventive effects achieved in $\mathrm{CP}$, the existing problems, the cooperation with the local community and the changes necessary to improve $\mathrm{CP}$ implementation.

The respondents from the regional police departments of Novi Sad, Niš and Kragujevac headed the Section for Organization, Prevention, Training and Community Policing. As it is evident form the section's title, the responsibilities of this Section included other tasks apart from the prevention and CP. In the mentioned regional police departments, $\mathrm{CP}$ policing positions established in the mentioned Sections were not filled or the officers who were assigned to these positions performed other tasks, at the behest of the department manager. Police officers at the Department for Prevention and Community Policing in the Police Department for the City of Belgrade did not perform tasks within the competence of the department at all; instead they performed tasks related to internal affairs control. The Department for Prevention and Community Policing at the Uniformed Police Department in Police Directorate conducted tasks within its competence. 
The respondents stated that since the period of initial implementation of the $\mathrm{CP}$ in the Republic of Serbia, certain activities were undertaken, among which the most important were: lectures in schools, holding of forums and implementation of several projects of problem-oriented police work and daily visits to the policing sectors. In regional police departments, $\mathrm{CP}$ projects were implemented only at the level of the police department, not at the local level, that is, the level of police stations. These projects were rare - one or no project per year. According to the interviewees, the activities undertaken in the regional police departments did not yield any significant preventive effects, nor did they increase the citizens' trust in the police. However, significant preventive effects were achieved in schools, by introducing the work of school police officers, implementing the projects "School without Drugs and Violence", "Safe Childhood - Development of a Safety Culture of Youth", "Stop Peer Violence" and they were manifested through the reduction of crimes and misdemeanours in and around schools.

Talking about the problems that made the CP concept implementation difficult, the respondents said the most pronounced are the lack of safety councils in municipalities, the lack of awareness among police officers about the importance of prevention and community po- licing, police overload with other tasks, the lack of citizens' trust in the police and the lack of financial resources for the implementation of projects of problem-oriented police work. Some respondents felt that additional training was not required for police officers to perform these tasks, and their response was not substantiated by facts that would clarify this further.

The cooperation of police and representatives of local communities has been reduced mainly to contacts on various bases, without their involvement in solving any security problem. In order to involve all local community entities in solving security problems, the respondents emphasized that first the obligation of cooperation of local community entities with the police should be regulated by law, and second, that the local community leaders and all entities should be educated on the importance of CP and its effects. The respondents also pointed out that Security Councils, whose tasks should be regulated by law, should play a key role in establishing co-operation and initiating prevention in the local community.

All respondents agree on the need for a different organization of the CP implementation. They believed that establishing community policing officer position should be considered and that a special organizational unit (unit or section) for $\mathrm{CP}$ should be established in police stations and regional police departments.

\section{RESULTS ANALYSIS AND DISCUSSION}

After more than a decade since its inception into police practice, CP should have been a daily routine for police work. However, the results of the presented research are not encouraging. They tell us that preventive police activities are not only lacking in the daily routine of policing, but are also a rarity.

Analysing the results of the presented research, we can conclude that the lack 
of representation of the $\mathrm{CP}$ was influenced by several factors, among which the most important are the following: dysfunction of the police organizational structure, deep-rooted repressive model of police work, the lack of knowledge of police officers about the importance and models of community policing concept implementation, the lack of constant education and legally non-binding police and community collaboration (the work of Security Councils).

The beginning of police reform aimed at implementing the $\mathrm{CP}$ was accompanied by certain organizational changes. New police organizational units have been formed in the police organizational structure. Within the Uniformed Police Department at the Police Directorate, as well as within the Police Department for the City of Belgrade, a Department for Prevention and Community Policing was established. In the regional police departments within the Section for the Organization, Prevention, Training and Community Policing in Police Departments, executive officer positions (rank of captain and above) for community policing have been established. This organizational change should have created the foundations for further development and implementation of the CP concept. The new organizational units in the Police Departments and the position of executive CP officers inside regional police departments were to be the initiators and carriers of CP activities in the police departments. However, this did not happen. The Department for Prevention and Community Policing in the Police Department for the City of Belgrade did not perform the tasks for which it had been formed, but the tasks related to the internal affairs. The situation was similar with officers in regional police departments. In some regional police departments, the positions of the executive $\mathrm{CP}$ officers were vacant, while in other regional police departments, the officers in these positions performed other tasks. The tasks of the Department for Prevention and Community Policing of the Uniformed Police Departments in Police Directorate and the tasks of the executive CP officers in the regional police departments are managerial in their nature. Taking specific preventive activities and tasks in the area of CP was within the competence of the local police stations, whose responsibilities also included other police activities, such as detecting and solving crimes, maintaining law and order, securing public gatherings, handling requests and orders issued by state subjects (e.g. courts), etc. Police officers at police stations were expected to perform all these tasks and to achieve satisfactory results in all these activities. However, in practice, the situation is somewhat different, a large number of orders, requests and warrants issued by state subjects, frequent engagement of police officers in securing public gathering and other manifestations, the achievement of satisfactory repressive results, caused CP activities to be put to the background or completely neglected. According to it, at the very beginning of the CP implementation into the Serbian police, a mistake was made, which was reflected in non-separating the $\mathrm{CP}$ work into a separate organizational unit at the Police Directorate headquarters, regional police departments and police stations (specialization). In literature specialization is often stated as an important factor in CP implementation (Greene et al., 1994; Herbert, 1998; Carter \& Radelet, 1999; Feltes, 2002; Adams et al., 2005; Namgung, 2018). In this way, the CP work would be separated from other police affairs and would be 
carried out in separate organizational units of the police. Thus, specialized CP units in police stations would be able to carry out daily tasks in the field of $\mathrm{CP}$ without being distracted by other police activities. The performance of these organizational units would be measured by the number and content of activities implemented and the preventive effects achieved. Otherwise, the assignment of community policing activities to only a few police officers in police stations poses a real threat for these activities to be neglected, due to their frequent engagement in performing other tasks. For example, this was the case with the officers in the regional police departments and with the entire organizational unit in Police department for the City of Belgrade whose top responsibility was $\mathrm{CP}$ implementation. In countries with deep rooted traditional (reactive) police orientation, sometimes this could be the only way for CP implementation. Such a "specialized" approach should be, at some point in the future, replaced with "generalized" approach. Otherwise CP will not be truly implemented. Namely, the idea of CP specialization is not in accordance with the $\mathrm{CP}$ philosophy posing a great threat to "smother" it in a long term. By its nature CP philosophy implies a 'whole of organisation' approach because its principles should permeate activities of all police officers (Mastrofski, 2006). According to (Young and Tinsley, 1998)"if problem-solving and responsibility for crime prevention are assigned to specialised units without fundamental change in the rest of policing, the predominant philosophy and culture of the organisation will almost inevitably remain unchanged". At the same time, as it is noted by (Moore, 1992) "the creation of specialized units committed to community policing strat- egies may signify that "only" (added by the authors) officers in the units are mainly responsible for the implementation of diverse community policing programs". Not being able to be transformed into effective mainstream policing, $\mathrm{CP}$ may gradually disappear in the years to come.

In addition, performance measurement system still neglects $\mathrm{CP}$ activities. Crime prevention and other activities related to $\mathrm{CP}$ are either not valued at all, or in cases when they are taken into account during performance evaluation(s), they are less valued in comparison to other (reactive) activities.

The dominant orientation of the police towards the traditional way of work is also influenced by the lack of knowledge of police officers (not only front line police officers, but police managers too) about the importance of prevention and the modalities of CP implementation in practice. The requirement for the deployment of police officers to senior positions in police stations and senior management levels was not the possession of certificates about passing the exam for a head, which would cover legal subjects, leadership in the police, criminal justice, crime prevention, the work of the $\mathrm{CP}$ and the like. Instead, the requirement was simply to have a university degree in social science and a certain number of years of work experience. Thus, police officers whose education background was not achieved from police educational institution (e.g. University of Crime Investigation and Police Studies in Serbia), i.e. faculties that do not have any subject related to the criminal justice and/or police profession in their curricula, were assigned to management positions (Simonović, 2015). It should be added that these heads were not obliged 
to further develop their knowledge in the above-mentioned fields, which made their knowledge on crime prevention and the work of $\mathrm{CP}$ either lacking or at the level of general knowledge. ${ }^{4}$

Modern police work aimed at prevention, unlike traditional police work, requires police officers to have different array of knowledge and skills that can only be acquired and upgraded through education and training. For this reason, continuous education of all police officers on $\mathrm{CP}$ is important, which is agreed by the largest number of the respondents. The lack of education moves police officers away from prevention and community policing and returns them to traditional policing. The beginning of the CP implementation was accompanied by the relevant training of police officers. Leaders of different ranks (commanders, deputies and assistant commanders of the police station) and front line police officers participated in these trainings. During these trainings, police officers acquired basic or informative knowledge of $\mathrm{CP}$, which was not sufficient for the long-term implementation of this type of practice. After the initial implementation period there was no continuation of $\mathrm{CP}$ training in the police departments (e.g. no refresher trainings were offered).

Training of police officers is mostly needed when changes in police work are introduced, as was the case with the introduction of the $\mathrm{CP}$ concept. However, its significance is not lower later, when the newly established system needs to be maintained. New training should extend basic knowledge about the prevention and CP work. The training of police officers on crime prevention and $\mathrm{CP}$ should positively influence the change in their views and opinions on the need and importance of prevention and CP. Otherwise, the acquired knowledge and changed awareness could soon be lost and the police will continue with the traditional way of working, as the only learned work.

There is no effective police work without prevention and there is no prevention without partnership and cooperation with the local community. The respondent from the City of Belgrade Police Department, answering the question about cooperation with the local community, i.e. with the heads in municipalities in the city of Belgrade, said that some heads cooperated with the police in prevention and provided every kind of help and support, while others refused any form of cooperation because they were not bound by any legal act. Cooperation was upon the goodwill of local community heads (Milidragović, 2016: 167). Hence, cooperation between the police and local community representatives should not be based on goodwill and/or motivated with some political interests, but on the legal obligation to cooperate and form local security councils and other bodies, as well as to designate specific financial resources for the implementation of problem solving projects in the municipal budget. In this way, the problem of establishing cooperation between the police and the local community, the absence of local security councils and the lack of financial resources for the implementation of projects would be overcome, as the respondents also pointed out.

Unlike other similar researches, according to the authors' knowledge, this research is the only one in Serbia that entailed all 27 regional police departments. Apart from similar researches

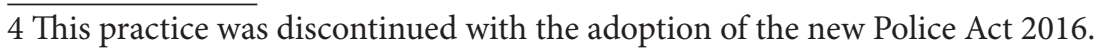


whose focus was on the attitudes of front line police officers, the present research focused on the middle management, particularly to those managers whose, if not the only then the most dominant responsibility was $\mathrm{CP}$ implementation. Interview conducted in this research also entailed a strategic manager (Police Directorate level) who was in charge of $\mathrm{CP}$ implementation in Serbia. This research would be of better quality if it had included police officers from other lines of police work, primarily members of the criminal police. Although they are on the streets daily and interact with the citizens (whose information often plays a crucial role in their crime solving efforts), there is an erroneous belief that they should not have any role when it comes to the
CP implementation. Usually they are exempted from any CP reform, not only in Serbia but in other countries too. The same can be applied to traffic police and some other police branches. In that regard, knowledge of how they view the $\mathrm{CP}$ and what their role, if any, should be in its implementation, remains as the idea for some future research. Finally, just as there is no community-free $\mathrm{CP}$, so no CP-related research could provide a complete picture if it does not include citizens. It would be interesting to see how community members evaluate police CP activities, if the police can be considered as a reliable partner, what they miss when it comes to CP policing and what message they would have to send to the police management.

\section{CONCLUSION}

Since the inception of CP in the Serbian police practice, numerous scientific papers and evaluations indicated the problems, mistakes and weaknesses related to the implementation of this concept, some of them offering suggestions and guidelines how to overcome them (Kešetovic, 2003; Mellish \& Đurđević, 2004; Vuković, 2004; Simonović, 2004; Downes, 2004; Ryan, 2005; Kešetović \& Davidović 2007; Ivetić, Mladjović, 2016). Although the examples of good practice are highlighted too, their general conclusion is that $\mathrm{CP}$ activities were insufficiently represented in the Serbian police practice - the conclusion also supported by the findings presented in this paper.

According to this research, the main impediments to greater CP implementation are: (1) predominantly repressive orientation of the police service. In the case where strong reactive orientation exists, CP activities are neglected; (2) Organizational structure which is not able to provide greater $\mathrm{CP}$ involvement through specialization.; (3) The lack of knowledge and skills related to CP concept; (4) The lack of legislation which could facilitate cooperation between the police and the community.

Since the beginning of the 2000s, when the CP implementation in the Republic of Serbia formally started, the periods when this concept was neglected were superseded by the periods when it was publicly proclaimed as one of the (strategic) priorities in the police work. Changes of police leadership, the lack of resources, the resistance of traditional police subculture that prefers crime fighting, the lack of community involvement etc., are just some factors that could divert Serbian MoI from the $\mathrm{CP}$ principles. However, commitment to 
CP implementation has survived to this day. Recently, the specialized police officers were introduced to all police stations. During the last decade, growing demands for calls for service, coupled with increasing paperwork (bureaucracy), left little time to CP activities. Introduction of specialized CP officers, whose sole responsibility is $\mathrm{CP}$ implementation, seems to be the only way for getting forward in the current constellation. A clearly defined scope of their work should be followed by allowing them greater discretion, accompanied with strict responsibility for the results achieved. This should further initiate changes to the performance appraisal system, where more value is put to activities and/or results related to problem solving and partnership building. The police officers' selection process should pay attention to skills such as analytical thinking and interpersonal communication which are nowadays neglected. Finally, there is a need for caution in order not to create animosity between "CP officers" and others in the police organization, by emphasizing daily communication and information exchange. The police leadership at the strategic level should send clear messages that the long-term goal of Serbian police is that entire police organization (not only uniformed patrol branch) adopts and acts according to the $\mathrm{CP}$ principles.
Winning "hearts and minds" of police officers and community members about the importance of the CP principles is an essential factor for its implementation. Police organizations should maintain constant education and training of police officers on the importance of the $\mathrm{CP}$ as well as to developing skills that are necessary in its daily implementation. At the same time, the benefits of police-community partnerships should be promoted in the (social) media. Police-community cooperation should be the subject of normative regulation, which will regulate clear obligations related to establishment and responsibilities of security councils, provision of funding for $\mathrm{CP}$ projects, etc.

Finally, we can state that with the introduction of CP police officers, a significant step has been made towards CP implementation. The mere introduction of specialized police officers, without affecting other problems, some of them already mentioned in this paper, will not guarantee sustainable CP implementation in the Serbian police. Ultimate goal should be focused on changing the organizational culture in a way it should become more conducive to CP. Otherwise specialized $\mathrm{CP}$ officer will be quickly "swallowed" by the rest of organization and CP in the Serbian police will continue to live a quiet life, where the CP activities will be, not a rule, but an exception.

\section{REFERENCES}

Adams, R. E., Rohe, W. M., \& Arcury, T. A. (2005). Awareness of community-oriented policing and neighbourhood perceptions in five small to midsize cities. Journal of Criminal Justice, 33(1), 43-54.

Bayley, D. (1994). Police for the future. New York: Oxford University Press

Brookes, S. (2006). Community policing in context. Crime Prevention and Community Safety, 8(2), 104-117. 
Bureau of Justice Assistance. (1994). Understanding community policing: A framework for action. US Department of Justice.

Carter, D. L., \& Radelet, L. A. (1999). The police and the community (6th ed.). Upper Saddle River, NJ: Prentice-Hall.

Chappell, A. T. (2009). The philosophical versus actual adoption of community policing: A case study. Criminal Justice Review, 34, 5-28.

Cordner, G. W. (1997). Community policing: Elements and effects in Dunham. In R. G. Dunham \& G. P. Alpert (Eds.), Critical Issues in Policing (pp. 451-468). Prospect Heights, IL: Waveland.

Cordner, G., \& Biebel, E. (2005). Problem-oriented policing in practice. Criminology \& public policy, 4(2), 155-180.

Cowell, B. M., \& Kringen, A. L. (2016). Engaging communities one step at a time: Policing' tradition of foot patrol as on innovative community engagement strategy. Washington, D.C: Police Foundation.

Diamond, D., \& Weiss, D. M. (2009). Advancing community policing through community governance: A framework document. U.S. Department of Justice, Department of Community Oriented Policing Services.

Downes, M. (2004). Police reform in Serbia: Towards the creation of a modern and accountable police service. Belgrade: Law Enforcement Department OSCE, Mission to Serbia and Montenegro.

Feltes, T. (2002). Community oriented policing in Germany: Training and education. Policing: An International Journal of Police Strategy and Management, 25(1), 48-59.

Feltes, T. (2013). Community policing in Germany. In K. Nalla Mahesh \& R. Newman Graeme (Eds.), Community policing indigenous communities (pp. 257-266). New York: Taylor \& Francis Group.

Forman, J. (2004). Community policing and youth as assets. The Journal of Criminal Law and Criminology, 95(1), 1-48.

Gill, C., Weisburd, D., Telep, C. W., Vitter, Z., \& Bennett, T. (2014). Community-oriented policing to reduce crime, disorder and fear and increase satisfaction and legitimacy among citizens: A systematic review. Journal of Experimental Criminology, 10(4), 399-428.

Goldstein, H. (1990). Problem-oriented policing. New York: McGraw Hill.

Greene, J. R., Bergman, W. T., \& McLaughlin, E. J. (1994). Implementing community policing: Cultural and structural change in police organizations. In D. P. Rosenbaum (Ed.), The challenge of community policing: Testing the promises (pp. 92-109). Thousand Oaks, CA: Sage.

Đorović, I. (2011). Struktura radnog vremena uniformisanih pripadnika policije sa osvrtom na PPU Kragujevac. Bezbednost, 53(2), 219-237. 
Haar, R. N. (2001). The making of a community policing officer: The impact of basic training and occupational socialization on police recruits. Police Quarterly, 4(4), 402-433.

Herbert, S. K. (1998). Police subculture reconsidered. Criminology, 36(2), 343-369.

Ivetić, M., \& Mlađovic, I. (2016). Stavovi i iskustva polaznika centra za osnovnu policijsku obuku o radu policije u zajednici u Republici Srbiji. Bezbednost, 53(3), 46-71.

Kelling, G. (1988). Police and communities: The quiet revolution: Perspectives on policing. Washington, DC: National Institute of Justice.

Kešetović, Ž. (2003). Reforma MUP-a Republike Srbije: od policije poretka ka servisu građana. Politička revija, 2(1), 209-228.

Kešetović, Ž., \& Davidović, D. (2007). Policing in Serbia: Challenges and developments. In G. Mesko \& B. Dobovsek (Eds.), Policing in emerging democracies: Critical reflections, (pp. 79-100). Ljubljana: University of Maribor, Fakulteta za varnostne vede.

King, W. R., \& Lab, S. P. (2000). Crime prevention, community policing, and training: Old wine in new bottles. Police Practice and Research, 1(2), 241-52.

Lobnikar, B., Cajner-Mraović, I., \& Faber, V. (2015). The Community policing evaluation: The pilot study in the Slovenian and the Croatian urban community. In Istraživački dani Visoke policijske škole u Zagrebu (pp. 511-524). Zagreb: Ministarstvo unutrašnjih poslova, Visoka policijska škola.

Lorie, F. (2004). The defining characteristics of community policing. In L. Fridell \& M. A. Wycoff (Eds.), Community policing: The past, present, and future: Police Executive Research Forum/Annie E. Washington, DC: Casey Foundation.

Maguire, E. R., \& Mastrofski, S. D. (2000). Patterns of community policing in the United States. Police Quarterly, 3(1), 4-45.

Mastrofski, S. (2006). Critic community policing: A sceptical view. In D. Weisburd \& A. Braga (Eds.), Police innovation: Contrasting perspectives: Cambridge studies in Criminology (pp. 44-74). Cambridge: Cambridge University Press.

Miller, L. S., Hess, K. M., \& Orthmann, C. M. (2008). Community policing partnership for problem solving. Boston: Cengage Learning.

Mellish, D., \& Đurđević, Z. (2004). Rezultati evaluacije projekta policija u lokalnoj zajednici i bezbedna zajednica u Srbiji. NBP: Nauka bezbednost, policija, 9(2-3), 215-234.

Milidragović, D., Subošić, D., \& Milić. N. (2019). Postupanje policije po naredbama i zamolnicama nadležnih subjekata. Žurnal za bezbjednost $i$ kriminalistiku, 1(1), 11-24.

Milidragović, D. (2016). Organizacija i delatnost policije opšte nadležnosti u prevenciji i represiji kriminaliteta (PhD thesis). Kragujevac: Univerzitet u Kragujevcu, Pravni fakultet. 
Milić, N. (2017). Mapiranje kriminala. Beograd: Kriminalističko-policijska akademija.

Milić N., Popović B., \& Marinković D. (2017). Research on Police Officers' Perception of Crime Hotspots in the Function of Improving Analytical Support of Policing. Revija za kriminalistiko in kriminologijo, 1, 15-30.

Milić, N. (2010). Aktuelni problemi organizacije i funkcionisanja policijske ispostave. In Pravo i forenzika u kriminalistici (pp. 115-128). Beograd: Kriminalističko-policijska akademija.

Moore, M. H. (1992). Problem-solving and community policing. Crime and Justice, $15,95-158$.

Moore, M., Trojanowicz, R., \& Kelling, G. (2000). Crime and policing. In O. Willard (Ed.), Community policing: Classical readings (pp. 41-59). London: Prentice-Hall.

Namgung, H. (2018). How can police agencies implement community policing? Create specialized units! International Journal of Law, Crime, and Justice, 52, 144-154.

Palmiotto, M. (2000). Community policing: A policing strategy for the 21st century. Boston: Jones and Bartlett Publishers.

Plačkov, R. (2008). Problemi rada policije na lokalnom području. Nauka-Bezbednost-Policija, 13, (3), 129-147.

Ryan, B., (2005). Deliberating police reform in Serbia (PPA Working Paper Series No. 9). Limerick: University of Limerick, Department of Politics and Public Administration

Simonović, B. (2015). Kriminalistika i unapređenje stručnosti krivično-procesnih subjekata. Revija za kriminologiju i krivično pravo, 53(1), 9-27.

Simonović, B. (2006). Rad policije u zajednici. Banja Luka: Viša škola unutrašnjih poslova.

Simonović, B. (2004). Komparacija pilot projekta community policing u SAD i Kanadi sa pilot projektima u Srbiji. In Rad policije u zajednici (pp. 13-34). Banja Luka: Visoka škola unutrašnjih poslova.

Skogan, W. (2004). Community policing: Common impediments to success. In L. Fridell \& M. A. Wycoff (Eds.), Community policing: The past, present, and future (pp. 159-167). Washington, DC: Annie E. Casey Foundation, Police Executive Research Forum.

Skogan, W. G., Hartnett, S. M., DuBois, J., Comey, J. T., Kaiser, M., \& Lovig, J. H. (1999). On the beat: Police and community problem solving. Nashville, TN: Westview Publishing Co.

Skolnick, J. H., \& Bayley, D. (1988) Community policing: Issues and practices around the world. Washington, DC: National Institute of Justice, Office of Communication and Research Utilization.

Trojanowicz, R., \& Bucqueroux, B. (1990). Community policing: A contemporary perspective. Anderson: Cincinnati, $\mathrm{OH}$. 
Vojnović, M. (2004). Policija u zajednici. Bezbednost, 46(3), 442-449.

Vuković, S. (2004). Problemi u implementaciji strategije community policing i mogućnost njihovog rešavanja. In Rad policije u zajednici (pp.71-94). Banja Luka: Visoka škola unutrašnjih poslova.

Zhao, J., Thurman, Q. C., \& Lovrich, N. P. (1995). Community-oriented policing across the U.S.: Facilitators and impediments to implementation. American Journal of Police, 14(1), 11-28.

Young, W., \& Tinsley, Y. (1998). Options for the development of COP/problem solving policing in New Zealand. Wellington: Victoria University of Wellington. 